\title{
Representation of Eco-spirituality Perspective in Baiat Cinta di Tanah Baduy by Uten Sutendy
}

\author{
Rahmi Rahmayati \\ Department of Indonesian Language and Literature \\ Universitas Negeri Surabaya \\ Surabaya, Indonesia \\ rahmirahmayati@unesa.ac.id
}

\begin{abstract}
This study described the representation of ecospirituality in the novel of Baiat Cinta di Tanah Baduy by Uten Sutendy. The analysis was conducted based on the study of ecocriticism. As the result, the characters who had eco-centric perspective showed positive attitudes toward the environment, like keeping and preserving the environment. In addition, the ecospiritual perspective of Baduy community in the novel was the way of thinking to see a nature spiritually, namely, belief that preserving and nurturing nature/environment was a God-given task to Baduy community which was done in the form of a daily ritual activity that reflected the spiritual value.
\end{abstract}

Key words: eco-spirituality, ecocentric, ecocriticism

\section{INTRODUCTION}

Human perspective on the environment is different from one another. A human perspective that prioritizes the harmonization and stability of the environment will bring positive attitudes towards the environment, such as respecting, keeping and preserving the environment, while human perspective which does not prioritize the balance of nature will bring negative attitudes toward the environment such as destruction and exploitation of natural resources excessively. Therefore, the human perspective on the environment determines the attitudes and behavior or actions of human beings towards the environment/nature. In addition, differences in human perspectives and attitudes toward the environment give an impact on the sustainability or destruction of the environment.

The difference perspective on the environment is presented in Baiat Cinta di Tanah Baduy by Uten Sutendy, published in 2015 by PT Adhi Kreasi Pratama Komunikasi. This novel illustrates the difference perspectives between Baduy community and the mining company PT Banten Nusantara Energy (foreigners who have no concern for Baduy) in cooperation with a foreign company, Sweden Petroleum and supported by unscrupulous officials in Banten.

This perspective is motivated by personal interests and certain groups who want to reap the benefits in Baduy by exploiting their natural resources, by drilling the oil.

Oil drilling has disrupted the environmental balance system in Baduy, such as the destruction of valleys, mountains, hills, forests, rivers, and trees and plants. The hills and mountains are cleared and torn down by heavy equipment (such as fellerbuncher and logging machine) and then the soil is taken to stock up the valley below which is the source of the mountain water so that it is flat to the ground. In addition, the trees and plants covered by the soil because of the fertile huma with a variety of wild plants are peeled off by heavy equipment used to knock downhills. So also with river water pollution due to contaminated various waste oil drilling.

The condition is due to human attitudes and behavior in treating nature/environment exploitatively. This attitude is based on an anthropocentric perspective that says human interest is more important than non-human interest (in this case nature) as Buell [1] suggests that anthropocentric are the assumption or view that the interests of humans are of higher priority than those of nonhumans. An anthropocentric perspective (centered on humans) is always opposed to an ecocentric perspective, a nature-centered (non-human) perspective. This is in accordance with Buell [1] that ecocentric is the interest of the ecosphere must override that of the interest of the individual species.

This ecocentric perspective is owned by the Baduy community described in Baiat Cinta di Tanah Baduy by Uten Sutendy. The attitude of Baduy community is to appreciate, maintain, and preserve the natural environment, and to fight against the foreigners who do not have concern for Baduy and do the destruction for the sake of personal interests and certain groups. The ecocentric perspective of the Baduy community in the novel is a manifestation of the eco-spirituality perspective possessed by the Baduy community, namely the view that keeping and preserving the environment is a God-given task to them.

In addition, they have conventions that show spiritual perspectives toward the environment that are always held firmly by the Baduy community at all age levels. According to Sutendy, [2] the convention is: "The mountain shall not be melted; the valley shall not be destroyed; the short shall not be joined; the length shall not be cut, the distinct shall be divided, whither shall it be answered". Further, Sutendy [2] explained that convention is implemented Baduy community as a daily ritual activity and reflects the spiritual value. 
Fios [3] explained that Skolimowski introduced a new paradigm which he calls eco-philosophy (eco-philosophy). Fios stated that the main force of the principle of eco-philosophy is a new way of thinking that sees nature spiritually [3]. Further Fios revealed that ecophilosophy is the same meaning and substance with a new eco-spiritual (spirituality of the natural environment) for the good of nature and the environment.

Fios expressed that Skolimowski showed clearly his ecological view of the noble values of the natural environment as a sacred basic substance. Fios added that humans should play a role in preserving the natural sacredness by developing positive attitudes to protect the glorious and noble nature. The eco-spiritual vision becomes a religious-spiritual imperative for humans or anyone who has a high commitment and good faith to maintain and preserve the earth's ecological area [3].

Although ecophilosophy is a new paradigm introduced by Skolimowski, the ecophilosophical (eco-spiritual) perspective exists or is shared by traditional societies. This is as expressed by Nurmardiansyah[4] that the way people view and behave in interaction, both with nature and with other humans in the whole ecosystem, actually already exist in traditional society or indigenous people with traditional knowledge which is also known as local wisdom (local wisdom). Nurmardiansyah added that traditional communities or indigenous peoples with traditional knowledge are better able to preserve the environment than modern life. In addition, traditional societies have extensive and deep knowledge in protection and management their environment, which is used to manage resources as best as possible[4].

The eco-spiritual perspective of the traditional society is described in Baiat Cinta di Tanah Baduy by Uten Sutendy. The eco-spiritual perspective in the novel can be studied using ecocriticism theory. This is because eco-spiritual perspectives (including ecocentric perspectives) are related to ecology, whereas the descriptions of the eco-spiritual perspective of characters in novels relate to literature. Ecocriticism is a combination of two disciplines between ecology and literary theory as Harsono said that ecocriticism theory is multidisciplinary, on the one hand, ecocriticism using literary theory and on the other using ecological theory[5]. In addition, Garrard stated that ecological knowledge is not only to see the harmony and stability of the environment, but also to know human attitudes and behavior [6]. Therefore, according to him, the eco-criticism analysis is interdisciplinary that extends to other disciplines, namely literature, culture, philosophy, sociology, psychology, environmental history, politics and economics, and religious studies.

Nugraha suggested that as a concept, ecocriticism became well-known in the 1970s in a WLA (The Western Literature Association) conference. In addition, Nugraha explained that through his essay "What is Ecocriticism?", Michael P. Branch traced the term ecocriticism at first was used by William Rueckert (1978) in his essay "Literature and Ecology: An Experiment in Ecocriticism". Further, Nugraha added that according to Branch, these ecocriticism and ecological terms became very dominant before WLA, which was re-implemented in 1989. And at that time, Glotfelty urged the term ecocriticism to be used as a criticism previously known as the study of nature writing [7].

Glotfelty argued that ecocritics is the study of the relationship between literature and the physical environment, earth-centered literary studies [8], while Kerridge revealed that ecocritics want to track ideas about the environment and its representation [9].

Wellek and Warren revealed that in the area of literary theory, an ecocritical theory can be traced in the paradigm of mimetic theory which has the basic assumption that literature is related to reality [10].

Based on these matters, the issues discussed in this study are 1) ecocentric perspective and attitude of the characters in Baiat Cinta di Tanah Baduy by Uten Sutendy toward the environment/nature; 2) eco-spirituality perspective of Baduy community in the novel.

\section{METHOD}

This study used a qualitative descriptive method. This method is a method that examines an object that occurs today. This method aims to describe facts, traits, and relationships between phenomena that are being investigated systematically, factually, and accurately. In this study, the method was used to describe ecospiritual perspectives (including ecocentric perspectives and attitudes toward the environment) represented in Baiat Cinta di Tanah Baduy by UtenSutendy in an ecocritical perspective.

The stages of this study were: 1) data collection and classification, 2) data analysis, 3) data interpretation, and 4) conclusion of data result. The first step, data collection and classification were done by collecting the primary data (Baiat Cinta di Tanah Baduy by Uten Sutendy) and the secondary data (various ecocritical references related to story characterization, i.e. human perspective/ story character to the environment). Then, the data were classified based on problems of the study.

The second stage, the data analysis was done by analyzing the data that has been classified based on problems of the study by using ecocriticism study. The third stage, the data interpretation was done by interpreting the results of data analysis based on ecocriticism study. The fourth stage, the conclusion of the data obtained by concluding the results of data based on data analysis and interpretation.

\section{DISCUSSION}

\section{A. Eco-centric Perspective of The Characters in Baiat Cinta di Tanah Baduy By Uten Sutendy and Attitudes towards the Environment/Nature}

In Baiat Cinta di Tanah Baduy by Uten Sutendy, an ecocentric perspective is owned by Baduy community leaders (including Jaro Nalim, Jaro Daenah, Musung, Mursyid's Father), Suten, and others. The ecocentric perspective of these characters is the view that there are interrelatedness and interdependence between humans and the environment. Humans and the environment are interdependent, need each other, and 
mutually support each other for the balance of ecosystems so that humans must maintain and preserve them. The perspective is manifested by their positive attitude toward the environment, that is not only by maintaining and preserving the environment/nature but also by opposing and fighting against people (foreigners) who do destruct to the natural environment in Baduy.

In this paper, ecocentric perspective and attitude of the characters in Baiat Cinta di Tanah Baduy who were analyzed they were Baduy community, Jaro Nalim, Jaro Daenah, Musung, and Mursyid's father. The analysis was as follows.

1) Ecocentric Perspective and Attitude of The Characters toward Environment in Baduy

Ecocentric perspective of Baduy community on the environment in this novel is described by Jaro Daenah. Jaro is Baduy's language which means village head. Jaro Daenah is the head of Kanekes village (one of the villages in Lebak, Banten). Jaro Daenah described the Baduy community's perspective on the environment as the following quotations.

"Orang Baduy menjaga sungai, kelestarian flora dan fauna, seperti layaknya menjaga diri dan anggota keluarga mereka sendiri," (page 14)

The above quote shows that the Baduy community has an ecocentric perspective because it considers nature as a part of themselves and their family.

"Siapa saja yang datang ke Baduy harus ikut menjaga kelestarian alam lingkungan. Tidak boleh menebang pohon, membuang sampah dan tidak boleh merusak kehidupan flora dan fauna. Seorang pedagang atau pendatang yang membuang sampah sembarangan akan mendapat teguran. Setiap rumah menyediakan tempat pembuangan sampah berupa karung atau kantong plastik yang disimpan di samping teras rumah"(page 14)

In the quotation, it is depicted that Baduy community has an ecocentric perspective. This is because of their strong commitment to the sustainability of nature by not letting anyone destruct the lives of flora and fauna.

"Jaro Daenah menyebutkan ada semacam konvensi yang secara turun temurun menjadi pedoman hidup Orang Baduy untuk melestarikan hutan agar tetap bersih, utuh, dan terjaga secara alami." (page 14)

"Konvensi itu selalu dipegang teguh masyarakat dari semua lapisan usia: gunung tidak boleh dilebur, lembah tak boleh dirusak, yang pendek tidak boleh disambung, yang panjang tidak boleh dipotong, yang berbeda dibedakan, yang iya diiyakan" (page 14)

"Dengan ajaran itu orang Baduy yakin bahwa melestarikan hutan merupakan kegiatan ritual sehari-hari dan mencerminkan nilai spiritual." (page15)
The above three quotations indicate that the convention held firmly by Baduy community hereditary is an ecocentric view, which is oriented towards nature/environment.

Here are the quotes that show the attitude of Baduy community toward the environment/nature in Baduy.

"Orang Baduy tidak menggantungkan kebutuhan hidup pada hewan yang hidup di air, seperti mencari ikan atau membuat empang dan tambak ikan. Sungai-sungai dibiarkan apa adanya, tanpa ada bendungan atau pengaliran air untuk budidaya ikan. Menurut mereka, memanfaatkan sungai untuk memenuhi kebutuhan hidup sehari-hari sama saja dengan merusak kelestarian alam. Dari sungai semua kehidupan di darat itu bermula. Sungai tidak boleh dikotori. Biarkan airnya mengalir." (page16)

The above quote shows the attitudes of Baduy community towards the environment/nature, namely by not relying on the necessities of life on living creatures that exist in the water and not utilizing the river for daily needs because the river functions are very important for the life of living things.

"Air minum yang mereka minum adalah air yang benarbenar asli belum terkontaminasi oleh bakteri dan unsur kimiawi. Nasi yang dimakan, dedaunan yang dikonsumsi sebagai lalapan, berasal dari pohon-pohon yang ditanam dan tumbuh tanpa pupuk kimiawi. Begitu juga ikan sungai yang ditangkap dan dikonsumsi, umumnya belum terkontaminasi oleh kotoran limbah. Kotoran limbah yang masuk ke air sungai bisa mereduksi kualitas protein dalam tubuh ikan."(page 41)

In the quotation above, it is illustrated that the attitudes of Baduy community shows their concern for the existence of clean and natural environment in their daily life, such as drinking water that has not been contaminated by bacteria and chemical elements, edible rice, fresh vegetables are foliage derived from trees grown without fertilizer chemical.

2) Ecocentric Perspective and Attitude of Jaro Nalimtowards The Environment/Nature in Baduy

Jaro Nalim's character in this novel is one of the traditional figures in Baduy. He is the Deputy of Puun (the highest leader in the customary government) of Kampung Baduy Dalam, Cikartawana. Jaro Nalim has an ecocentric view of the environment because he holds the Baduy convention that aims to maintain and preserve the earth. This is evidenced by the following quotations.

"Biarkan saja. Lihat saja, nanti juga mereka akan merasakan akibatnya. Merusak alam, apapun alasannya, sama halnya dengan merusak tubuh sendiri. Orang di luar sana merusak bumi demi mengejar kekayaan dan kekuasaan. Bumi seharusnya dijaga seperti kita menjaga tubuh sendiri. Apa yang ada di bumi ada di dalam tubuh kita. Mereka sekarang sedang merusak tubuhnya sendiri." (page 155) 
Based on the quote, Jaro Nalim has an eco-centric perspective because he believes that destroying nature means destroying himself and preserving nature means taking care of himself.

"Bumi sekarang sudah tua dan sedang sakit-sakitan. Kalau hutan di wilayah Baduy rusak, maka alam seluruh jagat raya bakal ikut rusak. Baduy adalah pancer (tiang) bumi." (page 155)

In the quote above, Jaro Nalim believes that Baduy people's belief is the pillar of the earth so that if the forest in Baduy region is damaged, then the whole universe will be destroyed.

"Yang kita hadapi adalah kekuatan besar. Sebaiknya kita sampaikan saja kepada pemerintah pusat dan daerah. Kita harus mengutarakan apa yang terjadi sebenarnya supaya pemerintah membatalkan rencana eksploitasi minyak di tanah ulayat." (page 160)

"Hal tersebut menurutnya penting, agar pemerintah dan masyarakat luar menyadari, bahwa bila tanah adat Baduy dan hutan di sekitar Ujung Kulon benar-benar rusak, maka keseluruhan bumi juga akan ikut rusak. "(page 160)

The quotations show the concern of Jaro Nalim to the Baduy environment by the influence of Baduy's people to cancel/reject of oil exploitation plan in Baduy's areas.

3) Ecocentric Perspective and Attitude of Jaro Daenah towards The Environment/Nature in Baduy

As mentioned earlier, Jaro Daenah is the head of Kanekes village (one of the villages in Lebak, Banten). This figure has an ecocentric perspective because he is not only believing and upholding the convention of Baduy community as described previously but also having a positive attitude toward the environment by maintaining, preserving and behaving issues related to Baduy environment. The evidence is presented as follows.

"Kita tak bisa membiarkan orang luar seenaknya merusak alam. Itu melanggar hukum adat. Gunung jangan dipugar, lembah jangan ditimpah. Yang panjang biarkan panjang, yang pendek biarkan pendek. Kita harus mencegah!" (page 160)

The quote above is the statement of Jaro Daenah in the gathering /meeting of all traditional leaders and village elders in Baduy Luar. The statement shows an ecocentric perspective toward the environment/nature.

4) Ecocentric Perspective and Attitude of Musung towards The Environment/Nature in Baduy

Musung is the son of Baduy's figure who lives in Kampung Gajeboh. Musung became a guide for the tourists who stay at his house. In addition, he also sells various products. This character is very persistent in opposing the establishment of oil drilling projects in Baduy's areas because he thinks it will destruct the environment and the convention of Baduy community. This shows that Musung has an ecocentric perspective as well as the following quotations.

"Musung sebagai wakil pemuda agak ngotot. Dia meminta agar ada tindakan lebih keras, dengan cara melakukan aksi demonstrasi kepada para petugas lapangan di lokasi proyek."'(page 160)

"Kita harus cegah mereka. Jangan sampe merusak! Kita harus protes, kalau perlu kita hentikan proyek itu," (page 166)

The quotations above illustrate that Musung insists against the environmental destruction by private companies and foreign companies by conducting demonstrations to officers at the site of an oil drilling project. This shows that Musung has an ecocentric perspective because he tries to protect the environment from destructive efforts by outsiders.

"Kami ingin menyampaikan pesan dari para kokolot. Pekerjaan proyek ini harus berhenti dulu, sebab mengganggu ketentraman masyarakat." (page 170)

The quote describes the attitude/action of Musung to the officer at the location of the oil drilling project. Musung and his friends went to the field officers of the project and conveyed the messages of Baduy's elders to them (the company) to stop the oil drilling project because it disturbs the tranquility of Baduy community. This is a manifestation of the eco-centric perspective of Musung to the environment.

5) Ecocentric Perspective and Attitude of Ayah Mursyid (Alim) towards The Environment/Nature in Baduy

Mursyid's father in this novel is not a real name. The real name is Alim. The character is often called Mursyid' Dad because as the name of honor as the parent of the first son of a boy named Mursyid (page 20). Mursyid's father or Alim is a public figure because he is a Deputy Head of the Village (Jaro) of Baduy Dalam. This character holds the belief/ conviction and convention of Baduy community in maintaining and preserving environment/nature in Baduy. In addition, this character has a real attitude/action in facing the threat of environmental damage, namely by coming to the government and convey the aspirations of Baduy community to the government. The description is like the following quotations.

"Inilah kami dari dulu seperti ini adanya. Kami cucu Nabi Adam yang bertugas menjaga dan melestarikan alam. Jadi, kami moal (tidak) berubah walaupun orang di luar terus berubah karena alam Baduy dan isinya adalah titipan Tuhan yang tak boleh dirusak," (page 27)

The quotation above shows the ecocentric perspective, namely the belief of Mursyid's father that the Baduy community as the descendant of Prophet Adam who has the duty to maintain and preserve nature. They will not change although people outside Baduy changes in many things because they believe that the nature of Baduy and its contents is a deposit of God that should not be destroyed. 
"Kami mohon kepada pemerintah supaya meninjau ulang izin pengeboran minyak di wilayah tanah Baduy dan Ujung Kulon. Kalau bisa, benar-benar dihentikan karena berdampak serius kepada keutuhan dan keseimbangan ekosistem hutan." (page 168)

The above quotation was expressed by Mursyid's father (Alim) as a representative of the Baduy community during the Saba Village event. This activity is conducted every year by Baduy people with the aim that the government listen to the aspirations presented by the public figure (elders) ofBaduy community.

6) Eco-spirituality Perspective in Baiat Cinta di Tanah Baduy By Uten Sutendy

Eco-spiritual perspective is represented by Baduy community in BaiatCinta di Tanah Baduy by Uten Sutendy. The eco-spiritual perspective is the belief that preserving and nurturing the environment is God's given to them. In addition, the eco-spiritual perspective is manifested in the ideology of Sunda Wiwitan that has been integrated and internalized in the customs/daily life of Baduy people. It is described in the following quotations.

"Gusti Allah memberikan kami tanggung jawab untuk memelihara dan melestarikan lingkungan” (page 26)

In the above quotation, Baduy people believe that preserving and conserving the environment is a responsibility that must be performed by them because the responsibility is given by God.

“Ajaran Sunda Wiwitan yang berkembang di masyarakat Baduy bertugas mengurus alam agar lestari. Oleh karena itu, dalam praktiknya, ajaran ini bersatu dengan adat istiadat kehidupan sehari-hari sehingga nyaris tak dapat dibedakan mana ajaran Sunda Wiwitan dan mana yang merupakan kebiasaan atau adat istiadat." (page 27)

The above quotation indicates that Baduy community develops the ideology of Sunda Wiwitan in charge of preserving and conserving the environment/nature. In the development and practice, the ideology is integrated with the customs/daily life of Baduy people.

"Inilah kami dari dulu seperti ini adanya. Kami cucu Nabi Adam yang bertugas menjaga dan melestarikan alam. Jadi, kami moal (tidak mau) berubah walaupun orang di luar terus berubah, karena alam Baduy dan isinya adalah titipan Tuhan yang tak boleh dirusak, "(page 27)

The quote describes the eco-spiritual perspective of the Baduy community because the quotation above shows that the Baduy community since the last time have the task of preserving and conserving nature. In addition, they have the principle that until whenever they will not change even though people/community outside Baduy experience change continually because nature/environment in Baduy is a deposit of God that should not be destroyed.

"Orang Baduy Luar meyakini kalau orang tua mereka di Baduy Dalam adalah 'orang suci' yang sedang bertapa menjaga kelestarian alam. Secara intensif, mereka melakukan komunikasi batin dengan Tuhan, sang pencipta alam. Kebersihan dan kesucian jiwa mereka dianggap bisa langsung berhubungan dengan Tuhan, mampu merasakan getaran alam dan membaca tanda-tanda zaman" (page 33)

In the quotation, it is depicted that community of Baduy Luar believe that their elderly people in Baduy Dalam are "saints" who are meditating (praying) for the sustainability of nature. The saint (ascetic) intensively communicates with God, the creator of nature. They are believed and regarded as people who can directly relate to God and have the ability to feel and read natural phenomena and signs of the times because of the cleanliness and purity of their souls. This shows that the Baduy community has an eco-spiritual perspective.

"Kami memperlakukan padi dan semua pohon dengan baik, sama seperti kami mengurus anak kami sendiri. Mereka tidak diberi racun sebagaimana para petani di luar sana. Tiap akan mulai menanam dan saat akan memetik hasil panen, kami berdoa supaya hasil panen penuh berkah. Itu sebabnya alam memberi kekuatan kepada orang Baduy." (page 40)

The above quotation shows that Baduy community is consistent with their eco-spiritual perspective. This is evidenced by the quote that describes the view of Baduy people who treat rice and all trees well. They care for rice and all trees like taking care about their own children by not using chemicals. In addition, their eco-spiritual perspective is manifested by the habit of praying when they will plant and pick the harvest in the hope of blessing the harvest. They believe that nature will give them power if they do these things.

"Dalam keyakinan mereka, segala yang ada di alam termasuk yang mereka makan sehari-hari adalah makhluk Tuhan yang juga memiliki ruh kehidupan. Cara hidup orang Baduy yang bersahaja terutama dalam memperlakukan alam dan lingkungan membuat mereka senantiasa mendapat dukungan dan penguatan dari alam di manapun mereka berada." (page 41)

The quotation confirms that the eco-spiritual view is integrated and internalized in the daily life of Baduy people. This is shown by quotations that illustrate the belief that everything in nature, including what they eat, is a creature of God who has the spirit of life. In addition, the way Baduy people live in treating nature and the environment makes them have the support and reinforcement of nature wherever they are.

"Orang Baduy hidup di lokasi yang disebut Pancer Bumi (tiang bumi), daerah yang tergolong inti jagat. Maka keseluruhan nilai-nilai adat dan agama yang melandasi sikap hidup sehari-hari mereka berorientasi untuk menjaga dan 
melestarikan bumi. Baduy dan lingkungannya adalah cengcelengan pangeran (tabungan Tuhan) yang tak boleh berubah dan bergeser sedikitpun hanya karena rongrongan dan desakan pengaruh modernisasi." (page 59)

In the above quotation, the eco-spiritual perspective of Baduy community is reflected on the values of tradition and religion that underlies their attitude and their daily way of life oriented in preserving and conserving the earth. In addition, their beliefs about Baduy and their environment are God's saving that should not be changed and shifted a bit because of the insistence of modernizing influence.

\section{CONCLUSION}

The eco-spiritual and ecocentric perspectives and attitude of Baduy community to the environment are represented through the characters of the story in Baiat Cinta di Tanah Baduy by Uten Sutendy. The eco-spiritual perspective of the Baduy community is a belief, a life attitude, and a life-oriented way of preserving and conserving the environment/nature, while the eco-centric perspective of Baduy community is the view that humans and nature are dependent, need each other, and complements for the balance of the ecosystem. This ecospiritual and ecocentric perspective are manifested by the attitude and way of life of those who guard and preserve the environment/nature and fight against the outsiders who want to do environmental destruction in Baduy.

\section{REFERENCES}

[1] L. Buell, The Future of Environmental Criticism: Environmental Crisis and Literary Imagination. USA: Blackwell Publishing, 2005.

[2] U. Sutendy, Baiat Cinta di Tanah Baduy. PT Adhi Kreasi Pratama Komunikasi, 2015.

[3] F. Fios, "Eko-Spiritualisme: Sebuah Keniscayaan pada Era Kontemporer," Hum., vol. 4, no. 2, pp. 1237-1246, 2014.

[4] E. Nurmadiansyah, "Eco-philosophy dan Implikasinya dalam Politik Hukum Lingkungan di Indonesia," In Melintas, vol. 30, no. 1, pp. 70-104, 2014.

[5] S. Harsono, "Kritik Sastra Berwawasan Lingkungan,” J. Ekokritik, 2008.

[6] G. Garrard, Ecocriticism. London and New York: Routledge, 2004.

[7] F. Nugraha, "Sastra Hijau," Pikiran Rakyat, 2009.

[8] C. Glothfelty and H. Froom, The Ecocriticism Reader: Landmarks in Literary Ecology. London: University of Goergia Press, 1996.

[9] R. Kerridge and S. N., Writing the Environment. London: Zed Books, 1998.

[10] R. Wellek and A. Warren, Theory of Literature. Harmondsworth: Penguin Books, 1963. 